ORIGINAL ARTICLE

\title{
Rekreasyonel erkek futbolcularda dinamik germe ve miyofasyal gevşetmenin alt ekstremite sıcaklığı, esneklik, denge ve çeviklik üzerine akut etkilerinin karşılaştırılması
}

\author{
Erhan SEÇER ${ }^{1}$, Derya ÖZER KAYA ${ }^{2}$
}

Amaç: Bu çalışma; yalnız dinamik germe ile dinamik germe ve miyofasyal gevşetme yöntemlerinin alt ekstremite sıcaklığı, esneklik, denge ve çeviklik üzerine akut etkilerini karşılaştırmak amacı ile gerçekleştirildi.

Yöntem: Çalıșmaya 27 rekreasyonel erkek futbolcu (yaş 20,55 $\pm 1,47$ yıl; boy 174,70 $\pm 4,42 \mathrm{~cm}$; kilo 70,18 $\pm 8,67 \mathrm{~kg}$ ) dahil edildi. Çalışmanın birinci günü ilk 14 katılımcıya yalnız dinamik germe, son 13 katılımcıya dinamik germe ve miyofasyal gevşetme; çalışmanın ikinci günü ilk 14 katılımcıya dinamik germe ve miyofasyal gevşetme, son 13 katılımcıya ise yalnız dinamik germe uygulandı. Her iki günde de yöntemlerden önce ve sonra katılımcıların alt ekstremite sıcaklıkları termal kamera; esneklikleri otur-uzan; dengeleri Y denge ve çeviklikleri T testi ile değerlendirildi.

Bulgular: Yalnız dinamik germenin alt ekstremite sıcaklı̆ı̆, esneklik ve çevikliği; dinamik germe ve miyofasyal gevşetme yöntemlerinin ise alt ekstremite sıcaklığı, esneklik, denge (anterior, postero-medial, postero-lateral) ve çevikliği artırdığı sonucuna ulaşıldı $(p<0,05)$. Bununla birlikte dinamik germe ve miyofasyal gevșetme yöntemlerinin; alt ekstremite sıcaklığı, esneklik, denge ve çevikliği arttırmada yalnız dinamik germe yöntemine göre üstünlüğü olmadığı sonucuna ulaşıldı $(p>0,05)$. Sonuç: Çalışmanın sonucunda yalnız dinamik germenin alt ekstremite sıcaklığı, esneklik ve cevikliği; dinamik germe ve miyofasyal gevşetme yöntemlerinin alt ekstremite sıcaklığı, esneklik, denge ve çevikliği arttırdığı sonucuna ulaşıldı. Ayrıca dinamik germe ve miyofasyal gevşetme yöntemlerinin; alt ekstremite sıcaklığı, esneklik, denge ve çevikliği arttırmada yalnız dinamik germeye göre üstünlüğü olmadığı görüldü. Bu sonuçların performans öncesi ısınma protokolleri sırasında dikkate alınması gerektiği düşünülmektedir.

Anahtar kelimeler: Germe, Gevșetme, Esneklik, Denge.

Comparison of acute effects of dynamic stretching and myofascial release

on lower extremity temperature, flexibility, balance and agility in recreational male soccer players Purpose: To compare the acute effects of only dynamic stretching to dynamic stretching and myofascial release on lower extremity temperature, flexibility, balance and agility.

Methods: Twenty-seven recreational male soccer players (age 20.55 \pm 1.47 years; height $174.70 \pm 4.42 \mathrm{~cm}$; body weight $70.18 \pm 8.67 \mathrm{~kg}$ ) were included in the study. The first 14 athletes performed only dynamic stretching and the last 13 athletes performed dynamic stretching and myofascial release on the first day. On the second day; the first 14 athletes performed dynamic stretching and myofascial release, and the last 13 athletes performed only dynamic stretching. Temperature with thermal camera, flexibility with sit-and-reach; balance with $Y$ balance and agility with $T$ test were assessed before and after the methods in both days.

Results: Dynamic stretching improved lower extremity temperature, flexibility and agility $(p<0.05)$. Dynamic stretching and myofascial release improved lower extremity temperature, flexibility, balance (anterior, posteromedial, posterolateral), and agility $(p<0.05)$. However, dynamic stretching and myofascial release are not effective in increasing lower extremity temperature, flexibility, balance and agility as compared to only dynamic stretching $(p>0.05)$.

Conclusion: Dynamic stretching improved lower extremity temperature, flexibility and agility. Dynamic stretching and myofascial release improved lower extremity temperature, flexibility, balance, and agility. Dynamic stretching and myofascial release had no superiority in increasing lower extremity temperature, flexibility, balance and agility as compared to only dynamic stretching. It should be considered for pre-performance warm-up protocols.

Keywords: Stretching, Release, Flexibility, Balance.

1: Manisa Celal Bayar University, Faculty of Health Sciences, Physiotherapy and Rehabilitation, Izmir, Turkey. 2: İzmir Katip Celebi University, Faculty of Health Sciences, Physiotherapy and Rehabilitation, Izmir, Turkey Corresponding Author: Erhan Seçer: erhan.secer@cbu.edu.tr ORCID IDs (order of authors): 0000-0002-4476-3785; 0000-0002-6899-852X Received: April 29, 2020. Accepted: November 1, 2020. DOI: 10.15437/jetr.729553 
$\mathrm{G}$ ünümüzde herhangi bir fiziksel aktiviteye hazırlık aşamasında birçok profesyonel tarafindan kas performansinı arttırmak ve spor yaralanmalarını önlemek amacıyla gerçekleştirilen ısınma protokolleri; yapılan fiziksel aktivitelerin önemli bir parçası haline gelmiştir. ${ }^{1}$ Sporda performans öncesi uygulanan bu isinma protokolleri genellikle aerobik egzersiz, germe egzersizleri ve spora özgü aktivitelerden oluşmaktadır. ${ }^{2}$ Bunun yanı sıra sportif performans için optimum ısınma protokolünün belirlenmesi amacıyla yapılan çalışmalarda doku sağlığını ve performansını arttırmak amaciyla genel ısınma programlarının özellikle dinamik germeyi de içermesi gerektiği bildirilmektedir. . $^{3,4}$

Dinamik germe; agonist kas grubunun dinamik esnekliğini arttırmak amacıyla antagonist kas kasılmasını içeren önemli bir germe türüdür. ${ }^{5}$ Özellikle basit ve güvenli bir germe türü olmasından dolayı 'geleneksel bir yöntem' olarak kabul edilen statik germe, rutin isinma protokollerinde yaygin olarak kullanılsa da dinamik germenin statik germeye oranla sportif aktivitelerde performansı arttırmada daha etkili olduğu bildirilmektedir. ${ }^{6}$ Ayrica dinamik germenin sinir sistemi stimülasyonunda, vücut sıcaklığında ve antagonist kas inhibisyonunda artış meydana getirmesi ve bu durumun kas performansında artma ve spor yaralanmaları riskinde azalma ile sonuçlanması bu germe yöntemini ısınma protokollerinde önemli bir tercih haline getirmiştir. ${ }^{7}$ Ancak dinamik germenin farklı prosedürlerde uygulanmasından dolayı literatürde optimum dinamik germe protokolü konusunda net bir fikir birliğinin olmadığı bildirilmektedir. ${ }^{8}$

Son yıllarda birçok uygulayıcı tarafından spor ve antrenman performansinı en üst düzeye çıkarmak ve spor yaralanmalarını önlemek amaciyla geleneksel ısınma programlarına farklı yöntemler ilave edilmektedir. ${ }^{9}$ Özellikle son on yılda dinamik germeye alternatif olarak kullanımında giderek artış olan miyofasyal gevşetme bu yöntemlerden birisidir. ${ }^{10}$ Kas ve fasyaya basınç uygulayan birçok manuel terapi yöntemi için şemsiye terim olarak tanımlanan bu yaklaşım, bir materyal yardımı (köpük silindir) ile kişinin kendi kendine uyguladığı bir yöntemdir. ${ }^{11,12}$ Başka bir ifade ile mekanik kuvvet uygulamasının yumuşak dokulara etkisine dayanan manuel terapi yöntemleri için kullanılan ortak bir terimdir. ${ }^{13} \mathrm{Bu}$ yöntemin performansı olumsuz yönde etkilemeden farklı anatomik bölgeler için diğer ısınma protokollerinin içerisine dâhil edilerek kullanılabileceğini bildiren çalışmalar literatürde yer almaktadır. ${ }^{14,15}$ Bununla birlikte bu yöntemin sporda performansı arttırmada etkilerinin oldukça kısıtlı olduğu bildirilmektedir. ${ }^{16}$ Ayrica yakın zamanda yapılan bir literatür analizine göre optimum miyofasyal gevşetme yöntemi konusunda net bir uzlaşı olmadığı da görülmektedir. ${ }^{17}$ Literatüre bakıldığında farklı germe ve miyofasyal gevşetme yöntemlerinin sağlıkla ve performansla ilişkili fiziksel uygunluk parametreleri üzerine etkilerinin incelendiği bir çok çalışmaya rastlanmaktadır. Ancak ortaya çıkan sonuçlar oldukça farklılık göstermektedir. Bunun yanı sira sporcuların birçoğunun performans öncesi doku sıcaklıklarını arttırmak için ısınma programları uyguladıkları bilinmekte olup bu durum kasların ve yumuşak dokuların esneyebilme ve uzayabilme özelliğini olumlu yönde etkilemektedir. ${ }^{5}$ Böylelikle sporcunun performansı artmakta ve spor yaralanmaları riski de en aza inmektedir. Ancak literatürde farklı germe türlerinin ve miyofasyal gevşetme yönteminin doku sicaklığı üzerine etkilerini inceleyen sinırlı sayıda çalışma yer almaktadır. $\mathrm{Bu}$ doğrultuda bu çalışma; rekreasyonel erkek futbolcularda yalnız dinamik germe ile dinamik germe ve buna ek olarak uygulanan miyofasyal gevşetme yöntemlerinin alt ekstremite sicaklığı, esneklik, denge ve çeviklik üzerine akut etkilerini karşılaştırmak amacı ile gerçekleştirildi.

\section{YÖNTEM}

Çapraz çalışma tasarımı şeklinde planlanan çalışmaya Manisa Celâl Bayar Üniversitesi Sağlık Bilimleri Fakültesi’nde öğrenim gören 34 gönüllü üniversite öğrencisi dahil edildi. Yaş kriterine uymayan $(n=4)$ ve son üç ay içerisinde spor yaralanması geçirmiş olan $(n=3)$ öğrencilerin çalışma dışı bırakılmasıyla; çalışma 18-22 yaş arasında olan, son üç ay içerisinde herhangi bir spor yaralanması 
geçirmeyen, çalışma süresince ayrıca herhangi bir esneklik ya da germe programı uygulamayan ve haftada en az 2-3 gün düzenli futbol oynayan 27 gönüllü erkek üniversite öğrencisi (yaş ortalamaları $20,55 \pm 1,47$ yıl) üzerinde gerçekleştirildi. Çalışmanın akış şeması Şekil 1 'de verildi. Çalışma için gerekli olan etik kurul izni 8 Mayıs 2019 tarihinde Manisa Celâl Bayar Üniversitesi Tıp Fakültesi Sağlık Bilimleri Etik Kurulu'ndan alındı (Karar No: 20.478.486).

Çalı̧̧ma, Manisa Celâl Bayar Üniversitesi Sağllk Bilimleri Fakültesi Fizyoterapi ve Rehabilitasyon Bölümü Uygulama Laboratuvarı'nda bir hafta ara ile iki farklı günde gerçekleştirildi.

Her iki günde de değerlendirmelerin benzer saat aralıklarında (13:00-17:00) ve fiziksel ortam koşullarında (benzer kıyafet, zemin, sıcaklık) yapılmasına özen gösterildi.

Çalışma kapsamında katılımcıların alt ekstremite sıcaklıkları, termal kamera (Testo 882, Melrose, MA) ile birinci ve ikinci günde de uygulanan yöntemler öncesi ve sonrası sadece önden olmak üzere $2 \mathrm{kez}$ toplamda $4 \mathrm{kez}$ ölçüldü ve her iki alt ekstremite genelinde ortalama sıcaklık değerleri kaydedildi. Ölçümler sırasında, termal kamera yerden yaklaşı $50 \mathrm{~cm}$ yüksekliğe sabitlendi ve ölçümler 3 metre mesafeden gerçekleştirildi. Ölçümlerin yapıldığı uygulama laboratuvarı sıcaklığı, iklimlendirme cihazı ile oda sıcaklığı seviyesinde $\left(25^{\circ} \mathrm{C}\right)$ tutuldu. Ayrıca ölçümler gündüz saatlerinde gerçekleştirildiğinden herhangi bir aydınlatma cihazı kullanılmadı. Termal kamera, yüzeyel olarak vücutta oluşan termal tepkileri ölçen ve girişimsel olmayan bir yöntem olarak kullanılmaktadır ${ }^{18}$. Ayrıca bireye uygulanan herhangi bir yöntemin etkilerini objektif bir biçimde belirlemeye yarayan ve daha önce çalışmalarda kullanılan güvenilir bir araçtır. ${ }^{19}$

Esnekliğin değerlendirilmesinde 'oturuzan testi' kullanıldı. Otur uzan testi, esnekliğin değerlendirilmesinde geçerli ve güvenilir bir yöntemdir. ${ }^{20}$ Ölçüm öncesi oturuzan sehpası duvara sabitlendi, katılımcıların mat üzerinde ayak tabanlarını otur-uzan sehpasına yerleştirmesi, ardından bir deneme sonrası katılımcılardan dizlerini bükmeden üç kez olabildiğince öne doğru uzanmaları istendi ve değerler kaydedilip en iyi skor analiz için kullanıldı.

Dengenin değerlendirilmesinde ' $\mathrm{Y}$ denge testi' kullanıldı. Y denge testi, ölçümün tekrarlanabilirliğini geliştirmek ve performansını standartlaştırmak için yıldız denge testinin bir versiyonu olarak geliştirilmiş olup geçerli ve güvenilir bir yöntemdir. ${ }^{21}$ Testin hazırlanması sırasında üç adet mezura; anterior ile posterolateral ve posteromedial yöne uzanan mezuralar arasında $135^{\circ} \mathrm{lik}$, posteromedial ile posterolateral yöne uzanan mezuralar arasında $90^{\circ}$ lik açılar olacak şekilde zemine sabitlendi. Ölçümlerde standardı sağlamak için katılımcllardan; her iki ellerini de bellerinde sabitlemeleri, test edilmeyecek ayaklarını mezuraların tam birleşme yerinde sabit bir şekilde tutmaları, test edilecek ayaklarının parmak ucu ile mümkün olduğunca öne, solarkaya ve sağ-arkaya doğru uzanmaları ve parmak ucu ile uzanabildikleri noktaya dokunmaları istendi. Ölçüm dominant taraf için birer kez deneme sonrası üç kez yapıldı ve katılımcıların uzanabildikleri son noktaların ortalaması kaydedildi. Katılımcı test edilecek ayağı ile sert bir şekilde yere basarsa, test edilecek ayağı mezura dışında herhangi bir yere temas ederse, dengesi bozulursa, uzanmalar sırasında elleri vücudundan ayrilırsa, test geçersiz sayılıp tekrarlandı. Katılımcının test sırasında uzanabildiği son noktanın yüksek olması dinamik denge performansının iyi olduğunu gösterir.

Çevikliğin değerlendirilmesinde ise ' $\mathrm{T}$ testi' kullanıldı. $\mathrm{T}$ testi, çevikliğin değerlendirilmesinde kullanılan geçerli ve güvenilir bir yöntemdir. ${ }^{22} \mathrm{Bu}$ test için 4 adet antrenman çanağı ile ' $\mathrm{T}$ ' şeklinde bir çeviklik parkuru oluşturuldu ve çanaklar A, B, C ve D olarak isimlendirildi. Ayrıca çanaklar; A ile B arasinda $9,14 \mathrm{~m}$; $B$ ile $C$ ve $B$ ile $D$ arasinda ise $4,57 \mathrm{~m}$ mesafe olacak şekilde yerleştirildi. Katılımcllardan bir deneme ve dinlenme sonrası A noktasından B noktasına doğru koşmaları, B noktasına sağ elleri ile dokunmaları, B noktasından C noktasina doğru yan koşu yapmaları ve C noktasına sol elleri ile dokunmaları, C noktasından D noktasına doğru yan koşu yapmaları ve sağ elleri ile D noktasina dokunmaları, D noktasından B noktassına doğru yan koşu yapmaları ve sol elleri ile B noktasina dokunmaları ve B noktasindan A noktasina doğru geri geri koşmaları istendi. Test, 2 dakika dinlenme aralığı ile iki kez tekrarlandı ve en iyi skor kronometre ile ölçülüp 
kaydedildi.

Dinamik germe; hamstring, quadriceps, gastrocnemius ve gluteal bölge kaslarına 30 saniye süre (iki saniyede bir tekrar) ve 15 saniye dinlenme aralıkları ile uygulandı. ${ }^{23}$ Hamstring kas grubunun dinamik germesi sırasında; katılımcılardan hafif düz koşu eşliğinde alt ekstremitelerini sırası ile kalçadan itibaren öne doğru uzatmaları, quadriceps kas grubunun dinamik germesi sırasında; öne doğru yürürken dizlerini sırası ile hızlıca geriye doğru bükmeleri, gastroknemius kasının dinamik germesi sırasında; öne doğru yürürken önce topuklarını daha sonra parmaklarını yer ile temas ettirmeleri, gluteal bölge kaslarının dinamik germesi sirasında ise ayakta dik dururken bir ekstremitelerini geriye ve diğer tarafa götürmelerini daha sonra aksi yöne gövde rotasyonu yapmaları istendi. Miyofasyal gevşetme yöntemi ise yine aynı kas gruplarma olmak üzere 30 saniye süre (iki saniyede bir tur) ve 15 saniye dinlenme aralıkları ile uygulandı. ${ }^{24}$ Yöntem sirasında katılımcılardan; orta sertlikteki köpük silindir üzerinde, kendi ağırlıklarını kullanarak uygulama yapılan kasın başlangıç ve bitiş noktaları arasında ileriye ve geriye doğru yer değiştirmeleri istendi. Her iki yöntem de her iki alt ekstremite için toplamda altışar dakika süre ile uygulandı.

Çalışmanın birinci gününde katılımcılar öncelikle çalışmanın amacı ve çalışma kapsaminda uygulanacak testler ve yöntemler hakkında sözel ve uygulamalı olarak bilgilendirildi. Ayrıca katılımcılara gönüllü olur formu imzalatıldı ve katılımciların demografik bilgileri (yaş, boy, kilo vb.) veri kayıt formuna kaydedildi. Daha sonra beş dakikalık ısınma koşusunun ardından tüm katılımcılarm alt ekstremite sicaklığı, esneklik, denge ve çeviklik performansları değerlendirildi. İlk değerlendirmelerin ardından ilk 14 katılımcıya yalnız altı dakika dinamik germe; son 13 katılımcıya ise altı dakika dinamik germe ve altı dakika miyofasyal gevşetme yöntemleri uygulandı (Şekil 1). Uygulanan farklı yöntemlerin hemen ardından tüm katılımcıların alt ekstremite sıcaklığı ve performansları tekrar değerlendirildi.

Çalışmanın ikinci gününde (birinci günden bir hafta sonra) beş dakikalık ısınma koşusunun ardından tekrar tüm katılımcıların alt ekstremite sicaklığı, esneklik, denge ve çeviklik performansları değerlendirildi. İlk değerlendirmelerin ardından birinci gün yalnız altı dakika dinamik germe uygulanan ilk 14 katılımcıya altı dakika dinamik germe ve altı dakika miyofasyal gevşetme yöntemleri; ilk gün altı dakika dinamik germe ve altı dakika miyofasyal gevşetme yöntemi uygulanan son 13 katılımciya ise yalnız altı dakika dinamik germe uygulandı (Şekil 1). Uygulanan farklı yöntemlerin hemen ardından tüm katılımcıların alt ekstremite sıcaklığı ve performansları tekrar değerlendirildi.

\section{İstatistiksel analiz}

Çalışma için minimum örneklem genişliği; etki genişliği $\mathrm{dz}=0,591$ olmak üzere $\% 80$ test gücünü $\% 95$ güven düzeyinde sağlayacak toplam 25 kişi olarak hesaplandı. ${ }^{24}$ Örneklem genişliği G-Power 3.1.9.4. programı, veri analizi ise "IBM SPSS V22" programı kullanılarak yapıldı. Değişkenlerin normal dağılıma uygunluğu; Shapiro-Wilk Testi ve histogramların görsel olarak incelenmesi ile belirlendi. Grup içi ilk ve son ölçüm değerlerinin ve farklı yöntemlerin ilk ve son ölçümler arasında oluşturduğu farkların analizinde; parametrik test varsayımlarının sağlandığı durumlarda bağıml gruplarda t testi, sağlanmadığı durumlarda ise Wilcoxon testi kullanıldı. Tüm analizlerde I. Tip hata olasılığı (anlamlılık düzeyi) 0,05 olarak kabul edildi.

\section{BULGULAR}

Çalışmaya 27 gönüllü rekreasyonel erkek futbolcu dahil edildi. Futbolcularm demografik özelliklerine ilişkin bilgiler Tablo 1'de verildi.

Katılımcıların yalnız dinamik germe öncesi ve sonrası alt ekstremite sıcaklığı, esneklik ve çeviklik skorları ortalamaları Tablo 2'de verildi. Buna göre dinamik germe öncesi ve sonrası alt ekstremite sıcaklığı, esneklik ve çeviklik skorları ortalamaları karşlaştırıldığında istatistiksel olarak anlamlı bir fark bulunmuş olup alt ekstremite sıcaklığı, esneklik ve çeviklik skorlarında artış olduğu görüldü (sırasıyla, p=0,008, p=0,011, $\mathrm{p}=0,007$ ) (Tablo 2). Katılımcıların dinamik germe öncesi ve sonrası denge (anterior, postero-medial, postero- lateral) skorları ortalamaları Tablo 2'de verildi. Buna göre dinamik germe öncesi ve sonrası dinamik 
Tablo 1: Katılımcıların demografik özellikleri (N=27).

\begin{tabular}{lc}
\hline & $X \pm S D$ \\
Yaş (yıl) & $20,55 \pm 1,47$ \\
Boy (cm) & $174,70 \pm 4,42$ \\
Vücut ağırlı̆̆ı (kg) & $70,18 \pm 8,67$ \\
Beden kütle indeksi (kg/m²) & $22,95 \pm 2,59$ \\
Dominant taraf (Sağ/Sol) (n) (\%) & $22 / 5(81,5 / 18,5)$ \\
\hline
\end{tabular}

denge (anterior, postero-medial, posterolateral) skorlarinin ortalamaları karşılaştırıldığında istatistiksel olarak anlamlı bir fark bulunmadı (sırasıyla, $p=0,071$, $\mathrm{p}=0,237, \mathrm{p}=0,118$ ) (Tablo 2).

Katılımcıların dinamik germe ve buna ek olarak uygulanan miyofasyal gevşetme yöntemleri öncesi ve sonrası alt ekstremite sıcaklığı, esneklik, denge (anterior, posteromedial, postero- lateral) ve çeviklik skorları ortalamaları Tablo 2'de verildi. Buna göre dinamik germe ve buna ek olarak uygulanan miyofasyal gevşetme yöntemi öncesi ve sonrası alt ekstremite sicaklığı, esneklik, denge (anterior, postero-medial, postero-lateral) ve çeviklik ortalamaları karşılaştırıldığında istatistiksel olarak anlamlı bir fark bulunmuş olup alt ekstremite sıcaklığı, esneklik, denge (anterior, postero-medial, postero-lateral) ve çeviklik skorlarında artış olduğu görüldü (sirasiyla $p=0,001, p=0,005, p=0,011, p=0,003$, $\mathrm{p}=0,008, \mathrm{p}=0,002$ ) (Tablo 2). Katılımcılara uygulanan yalnız dinamik germe ile dinamik germe ve buna ek olarak uygulanan miyofasyal gevşetme yöntemlerinin ilk ve son ölçümler arasinda oluşturduğu farkların karşılaştırılması Tablo 3’te verildi. Buna göre farklı yöntemlerin alt ekstremite sicaklığı, esneklik, denge (anterior, postero-medial, postero-lateral) ve çeviklik performanslarının ilk ve son ölçümleri arasında oluşturdukları farklar arasında istatistiksel olarak anlamlı bir fark bulunmadı (sirasiyla, $p=0,384, p=0,456$, $\mathrm{p}=0,131, \mathrm{p}=0,339, \mathrm{p}=0,249, \mathrm{p}=0,348)$.

\section{TARTIŞMA}

Rekreasyonel erkek futbolcularda yalnız dinamik germe ile dinamik germe ve buna ek olarak uygulanan miyofasyal gevşetme yöntemlerinin alt ekstremite sıcaklığı, esneklik, denge ve çeviklik üzerine akut etkilerini karşılaştırmak amacıyla gerçekleştirilen bu çalışmada, yalnız dinamik germenin alt ekstremite sicaklığı, esneklik ve çeviklik performansını iyileştirirken dinamik germe ve buna ek olarak uygulanan miyofasyal gevşetme yöntemlerinin ise alt ekstremite sıcaklığı, esneklik ve çeviklik ile denge performansını da iyileştirdiği sonucuna ulaşıldı. Ayrıca iki farklı yöntemin; alt ekstremite kas sıcaklığı, esneklik, denge ve çeviklik performanslarının ilk ve son ölçümleri arasında oluşturdukları farklar incelendiğinde, dinamik germe ve buna ek olarak uygulanan miyofasyal gevşetmenin yalnız dinamik germeye göre üstün olmadığı görüldü.

Rana vd. statik ve dinamik germenin çeviklik ve vücut sıcaklığı üzerine etkilerini inceledikleri çalışmalarında 30 saniye süreler ile uygulanan statik ve dinamik germenin vücut sıcaklığını arttırmadığı sonucuna ulaşmışlardır. ${ }^{25}$ Bununla birlikte Chtourou vd. futbolcularda statik ve dinamik germenin sıçrama performansı üzerine etkilerini inceledikleri çalışmada 60 saniye süre ile uygulanan dinamik germenin vücut sıcaklığını anlamlı olarak arttırdığını bildirmişlerdir. ${ }^{26}$ Jeong vd. germe ve miyofasyal gevşetme (gevşetme topu masajı kullanarak) yöntemlerinin hamstring kas grubunun sıcaklığına olan akut etkilerini inceledikleri bir çalışmada toplamda 30 saniye ve üç set halinde uygulanan her iki yöntemin de kas sıcaklığını arttırmada yararlı olduğu sonucuna ulaşmışlardır. ${ }^{27}$ Bununla birlikte, Murray vd. quadriceps femoris kas grubuna 60 saniye süre ile uygulanan miyofasyal gevşetme yönteminin esneklik ve kas sıcaklığı üzerine etkilerini inceledikleri bir çalışmada bu yöntemin quadriceps kas grubunun sicaklığında anlamlı bir artış sağlamadığını ve özellikle sporcularda bu yöntemin daha uzun süreli uygulanması gerektiğini bildirmişlerdir. ${ }^{28}$ Literatüre bakıldığında iki farklı yöntemin sıcaklık üzerine etkilerinin incelendiği çalışmalarda farklı sonuçlar görülmektedir. Bizim çalışmamızın sonucunda ise her iki farklı yöntemin de alt ekstremite kas sıcaklığını arttırmada etkili olduğu sonucuna ulaşıldı. $\mathrm{Bu}$ sonuçlar doğrultusunda dinamik germe sirasında antagonist kasin kasılması ve 


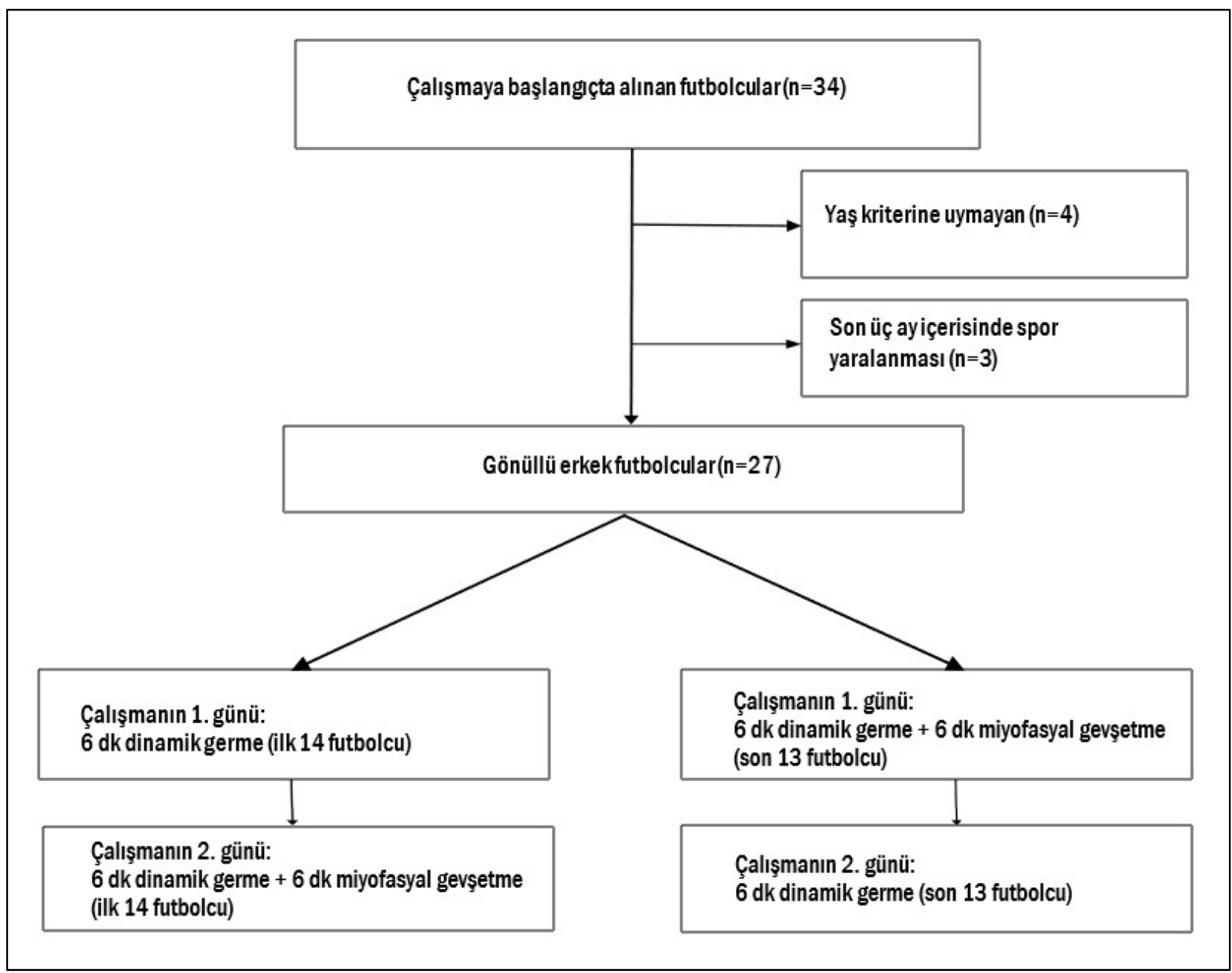

Şekil 1. Çalışmanın akış şeması.

miyofasyal gevşetme sırasında ise oluşan mekanik basıncin etkisi ile agonist kasta sıcaklık artışının sağlandığı düşünülmektedir. Bununla birlikte dinamik germe ve buna ek olarak uygulanan miyofasyal gevşetme yöntemlerinin alt ekstremite sicaklığını arttırmada yalnız dinamik germeye göre üstünlüğünün olmadığı görüldü. Bu çalışmada genel alt ekstremite sıcaklığı dikkate alındı ve kaslara özel olarak ya da tüm vücut ısısı için değerlendirme yapılmadı. Sicaklığın kaslara özel bakılması özellikle miyofasyal uygulamalar için önemli olabilir. Bu durum ileriki çalışmalar için göz önünde bulundurulmalıdır.

$\mathrm{Su}$ vd. isinma protokolü sirasinda 30 saniye süreler ile uygulanan statik germe, dinamik germe ve köpük silindir (miyofasyal gevşetme) yöntemlerinin esneklik ve kuvvet üzerine akut etkilerini inceledikleri bir çalışmada köpük silindir yönteminin diğer yöntemlere göre esneklik performansını arttırmada daha etkili olduğunu bildirmişlerdir. ${ }^{29}$ Adams vd. dinamik germe ve miyofasyal gevşetme yöntemlerinin kas gücü ve esnekliği üzerine akut etkilerini inceledikleri çalışmada 6 dakika süre ile uygulanan miyofasyal gevşetme yönteminin esnekliği arttırmada etkili olduğunu ancak dinamik germenin esneklik üzerine olumlu bir etkisinin olmadığını bildirmişlerdir. ${ }^{30}$ Nichol vd. statik germe, dinamik germe ve miyofasyal gevşetme yöntemlerinin kas gücü ve esnekliği üzerine akut etkilerini inceledikleri bir başka çalışmada ise 90 saniye süre ile uygulanan miyofasyal gevşetme yönteminin esnekliği arttırmada statik ve dinamik germeye göre daha etkili olduğu sonucuna varmışlardır. ${ }^{31}$ 
Tablo 2: Katılımcıların yalnız dinamik germe ile dinamik germe ve miyofasyal gevşetme yöntemleri öncesi ve sonrası alt ekstremite sıcaklığı ve performanslarının karşılaştırılması ( $\mathrm{N}=27)$.

\begin{tabular}{|c|c|c|c|c|}
\hline & & $\begin{array}{c}\text { Dinamik Germe } \\
\quad X \pm S D\end{array}$ & $\begin{array}{c}\text { Dinamik Germe+ } \\
\text { Miyofasyal Gevşetme } \\
\text { X } \pm \text { SD }\end{array}$ & $p$ \\
\hline Sıcaklık ( $\left.{ }^{\circ} \mathrm{C}\right)$ (önce) & & $33,54 \pm 0,78$ & $33,45 \pm 0,80$ & $0,747 \mathrm{~b}$ \\
\hline \multirow[t]{2}{*}{ Sıcaklık $\left({ }^{\circ} \mathrm{C}\right)$ (sonra) } & & $34,06 \pm 0,84$ & $34,16 \pm 0,12$ & $0,628 \mathrm{~b}$ \\
\hline & $\mathrm{p}$ & $0,008 * b$ & $0,001 * a$ & \\
\hline Esneklik (cm) (önce) & & $21,11 \pm 7,63$ & $22,74 \pm 7,30$ & $0,001 * a$ \\
\hline \multirow[t]{2}{*}{ Esneklik (cm) (sonra) } & & $21,77 \pm 7,02$ & $23,70 \pm 7,04$ & $0,001 * a$ \\
\hline & $\mathrm{p}$ & $0,011 * a$ & $0,005 * a$ & \\
\hline Denge (anterior) (cm) (önce) & & $72,31 \pm 4,98$ & $68,76 \pm 4,63$ & $0,001 * b$ \\
\hline \multirow[t]{2}{*}{ Denge (anterior) (cm) (sonra) } & & $73,10 \pm 5,37$ & $70,94 \pm 3,19$ & $0,011 * b$ \\
\hline & $\mathrm{p}$ & $0,071 a$ & $0,011 * b$ & \\
\hline Denge (posteromedial) (cm) (önce) & & $89,99 \pm 9,75$ & $93,75 \pm 6,83$ & $0,008 * b$ \\
\hline \multirow[t]{2}{*}{ Denge (posteromedial) (cm) (sonra) } & & $90,82 \pm 9,67$ & $95,46 \pm 6,44$ & $0,001 * b$ \\
\hline & $\mathrm{p}$ & $0,237 a$ & $0,003 * b$ & \\
\hline Denge (posterolateral) (cm) (önce) & & $95,87 \pm 4,95$ & $96,19 \pm 3,90$ & $0,602 b$ \\
\hline \multirow[t]{2}{*}{ Denge (posterolateral) (cm) (sonra) } & & $96,98 \pm 5,01$ & $98,40 \pm 3,74$ & $0,207 b$ \\
\hline & $\mathrm{p}$ & $0,118 b$ & $0,008 * b$ & \\
\hline Çeviklik (sn) (önce) & & $12,03 \pm 0,75$ & $11,68 \pm 0,79$ & $0,015 * a$ \\
\hline \multirow[t]{2}{*}{ Çeviklik (sn) (sonra) } & & $11,79 \pm 0,75$ & $11,34 \pm 0,65$ & $0,002 * a$ \\
\hline & $\mathrm{p}$ & $0,007 * a$ & $0,002 * a$ & \\
\hline
\end{tabular}

*: p<0,05. a: Bağımlı gruplarda t testi. b: Wilcoxon testi.

Tablo 3: Yalnız dinamik germe ile dinamik germe ve buna ek olarak uygulanan miyofasyal gevşetme yöntemlerinin ilk ve son ölçümler arasında oluşturduğu farkların karşılaştııılması ( $N=27)$.

\begin{tabular}{lcccc}
\hline & DG $(\Delta) X \pm S D$ & DG+MGY $(\Delta) X \pm S D$ & C & Cohen d \\
Sıcaklık $\left({ }^{\circ} \mathrm{C}\right)$ & $0,52 \pm 0,89$ & $0,71 \pm 0,82$ & $0,384 a$ & 0,17 \\
Esneklik (cm) & $0,66 \pm 1,27$ & $0,96 \pm 1,62$ & $0,456 \mathrm{~b}$ & 0,20 \\
Denge (ant) (cm) & $0,78 \pm 2,17$ & $2,17 \pm 3,97$ & $0,131 \mathrm{a}$ & 0,16 \\
Denge (post-med) (cm) & $0,83 \pm 3,57$ & $1,71 \pm 2,78$ & $0,339 \mathrm{a}$ & 0,18 \\
Denge (post-lat) (cm) & $1,10 \pm 3,56$ & $2,21 \pm 3,97$ & $0,249 \mathrm{~b}$ & 0,29 \\
Çeviklik (sn) & $-0,23 \pm 0,42$ & $-0,34 \pm 0,52$ & $0,348 \mathrm{a}$ & 0,18 \\
\hline
\end{tabular}

DG: Dinamik Germe. MGY: Miyofasyal Gevsetme Yöntemi. ant: Anterior. post-med: Postero-medial. post-lat: Postero-lateral. a: Bağımlı gruplarda t testi. b: Wilcoxon testi. Cohen d: Cohen etki büyüklü̈̆ü katsayısı.

Literatüre baktığımızda dinamik germe ve miyofasyal gevşetme yöntemlerinin esneklik üzerine akut etkilerini karşılaştıran çalışmaların yoğun olduğu bununla birlikte ortaya çıkan sonuçların farklı olduğu görülmektedir. Bizim çalışmamızın sonucunda ise her iki farklı yöntemin de esnekliği arttırmada etkili olduğu, ancak dinamik germeye ek olarak uygulanan miyofasyal gevşetme yönteminin esnekliği arttırmada yalnız dinamik germeye göre üstünlüğü olmadığı sonucuna ulaşıldı. Dinamik germe yönteminin olası bir sıcaklık artışı sağlayarak kas viskositesinde azalmaya neden olmasinın 
ve eklem hareket açıklığında bir artış sağlamasının esneklik performansını iyileştirmede etkili olduğu düşünülmektedir. Bununla birlikte dinamik germeye ek olarak uygulanan miyofasyal gevşetme yönteminin esnekliği arttırmada ek fayda sağlamaması; uygulama süresinin kas ve fasyanın sertliğini azaltmada yetersiz kalması ile açıklanabilir.

Benito vd. vibrasyonlu ve vibrasyonsuz köpük silindir yönteminin dinamik denge üzerine etkilerini inceledikleri bir çalışmada 60 saniye ve iki tekrar şeklinde uygulanan her iki yönteminde dinamik denge performansını arttırdığı sonucuna ulaşmışlardır. ${ }^{32}$ Bununla birlikte, Grabow vd., köpük silindir yönteminin denge üzerine etkilerini inceledikleri bir çalışmada 60 saniye ve üç set halinde uygulanan köpük silindir yönteminin dinamik denge performansina olumlu etkileri olmadığını belirtmişlerdir. ${ }^{33}$ Leblebici vd. farklı germe türlerinin dinamik denge üzerine akut etkilerini inceledikleri bir çalışmada beş yavaş ve ardından 10 hızlı tekrarlı ve üç set halinde uygulanan dinamik germe de dâhil olmak üzere farklı germe türlerinin dinamik denge performansı üzerine olumlu etkileri olmadığını bildirmişlerdir. ${ }^{34}$ Bununla birlikte Denerel vd. statik ve dinamik germenin dinamik denge performansı üzerine akut etkilerini inceledikleri bir çalışmada 30 saniye ve iki set halinde uygulanan dinamik germenin dinamik denge performansı üzerine olumlu etkilerini bildirmişlerdir. ${ }^{35}$ Literatürde yer alan çalışmalara baktığımızda dinamik germe ve miyofasyal gevşetme yöntemlerinin denge üzerine hem olumlu hem de olumsuz etkileri bildirilmektedir. Bizim çalışmamızın sonucunda ise yalnız dinamik germenin denge üzerine olumlu etkileri olmadığı, dinamik germe ve buna ek olarak uygulanan miyofasyal gevşetme yönteminin ise denge performansinı arttırdığı sonucuna ulaşıldı. Bu durum; miyofasyal gevşetme yönteminin uygulandığı bölgede yarattığı mekanik basıncın propriyoseptif girdiyi arttırması ile açıklanabilir. Ayrıca dinamik germe ve buna ek olarak uygulanan miyofasyal gevşetme yöntemlerinin yalnız dinamik germeye göre özellikle öne doğru uzanma sirasında denge performansında, artış sağlaması yöntemler öncesi öne doğru uzanma mesafelerinin farklı olmasından kaynaklanabilir. Bununla birlikte dinamik germe ve buna ek olarak uygulanan miyofasyal gevşetme yönteminin dengeyi arttırmada yalnız dinamik germe yöntemine göre bir üstünlüğü olmadığı görüldü. Her iki yöntemin birlikte uygulanmasının yalnız dinamik germe yöntemine göre dengeyi arttırmada daha etkili olabilmesi için miyofasyal gevşetme yönteminin daha uzun sürelerle uygulanması gerektiği düşünülmektedir.

Richmann vd. dinamik germe ve miyofasyal gevşetme yöntemlerinin eklem hareket açıklığı, sıçrama, sprint ve çeviklik performansı üzerine etkilerini inceledikleri bir çalışmada genel ısınma protokolüne ve dinamik germeye ek olarak 6 dakika süre ile uygulanan miyofasyal gevşetme yönteminin çeviklik performansına ek fayda sağlamadığı sonucuna ulaşmışlardır. ${ }^{24}$ Henning vd. köpük silindir yönteminin eklem hareket açıklığı, esneklik, vertikal sıçrama yüksekliği ve çeviklik performansı üzerine akut etkilerini inceledikleri bir çalışmada 20 sn süre ile uygulanan köpük silindir yönteminin çeviklik performansını arttırmada etkili olmadığını bildirmişlerdir. ${ }^{36}$ Bununla birlikte, Peacock vd. miyofasyal gevşetme yönteminin performans testleri üzerine akut etkilerini inceledikleri bir çalışmada dinamik ısınma programına ek olarak 30 saniye süre ile uygulanan miyofasyal gevşetme yönteminin çeviklik performansını arttırdığı sonucuna ulaşmışlardır. ${ }^{37}$ Dallas vd. farklı sürelerde uygulanan dinamik germenin çeviklik performansı üzerine etkilerini inceledikleri bir çalışmada ise dinamik germenin çeviklik performansını arttırmada etkili olduğunu bildirmişlerdir. ${ }^{38}$ Bizim çalışmamızın sonucunda ise iki farklı yöntemin de çeviklik performansını arttırmada etkili olduğu sonucuna ulaşıldı. Bu sonuçta; dinamik germe egzersizlerinin eklem hareket açıklığını arttırması ile kas performansının daha geniş eklem hareket açıklığında gerçekleşmesinin; miyofasyal gevşetme yönteminin ise yarattığ mekanik basıncın etkisi ile nöronların ateşlenme frekansında artış sağlamasının etkili olduğu düşünülmektedir. Bununla birlikte dinamik germe ve buna ek olarak uygulanan miyofasyal gevşetme yöntemlerinin çeviklik performansını arttırmada yalnız dinamik germe yöntemine göre üstünlüğü olmadığı sonucuna ulaşıldı. Bu durum; dinamik germeye ek olarak uygulanan miyofasyal 
gevşetme yönteminin uygulama süresinin yalnız dinamik germeye göre çeviklik performansinı arttırmada yetersiz olmasindan kaynaklanabilir. Denge parametresi ile benzer şekilde; her iki yöntemin birlikte uygulanmasının yalnız dinamik germe yöntemine göre çevikliği de arttırmada daha etkili olabilmesi için miyofasyal gevşetme yönteminin daha uzun sürelerle uygulanması gerektiği düşünülmektedir.

\section{Limitasyonlar}

Çalışmaya yalnız erkek bireylerin dâhil edilmesi, çalışmada kontrol grubunun olmaması ve $\mathrm{Y}$ denge testi sirasında bireylerin bacak uzunluklarına göre normalizasyon yapılmaması çalışmamızın limitasyonları arasindadir.

\section{Sonuc}

Çalışmamızın sonucunda dinamik germenin alt ekstremite kas sıcaklığı, esneklik ve çeviklik performansını; dinamik germe ve ek olarak uygulanan miyofasyal gevşetme yöntemlerinin ise alt ekstremite kas sıcaklığı, esneklik ve çeviklik ile birlikte denge performansını arttırdığı sonucuna ulaşıldı. Bununla birlikte, grupların sonuçlarının birbirine üstünlüğü olmadığg görüldü. $\mathrm{Bu}$ sonuçların performans öncesi ısınma protokollerinde dikkate alınması gerektiği ayrıca dinamik germe ve miyofasyal gevşetme yöntemlerinin spor yaralanmalarının önlenmesi açısından kronik etkilerinin de incelendiği çalışmalara ihtiyaç olduğu düşünülmektedir.

\section{Teşekkür: Yok.}

Araştırmacıların Katkı Oranı Beyanı: ES: Literatür araştırması, veri toplama, makale yazma; DÖK: Çalışma tasarımı, veri analizi/yorumlama, kritik gözden geçirme.

\section{Çıkar Çatışması: Yok.}

Finans: Yok.

Etik Onay: $\mathrm{Bu}$ araştırma protokolü Manisa Celâl Bayar Üniversitesi Tıp Fakültesi Sağlık Bilimleri Etik Kurulu (sayı: 20.478.486, tarih: 08.05.2019) tarafindan onayland.

\section{KAYNAKLAR}

1. Rahnama N. Preventing sport injuries: improving performance. Int $J$ Prev Med. 2012;3:143-144.

2. Romaratezabala E, Nakamura FY, Castillo D, et al. Influence of warm-up duration on physical performance and psychological perceptions in handball players. Res Sports Med. 2018;26:230243 .

3. Behm DG, Chaouachi A. A review of the acute effects of static and dynamic stretching on performance. Eur J Appl Physiol. 2011;111:2633- 2651.

4. Schleip R, \& Müller DG. Training principles for fascial connective tissues: scientific foundation and suggested practical applications. J Bodyw Mov Ther. 2013;17:103-115.

5. Yamaguchi T, Ishii K. Effects of static stretching for 30 seconds and dynamic stretching on leg extension power. J Strength Cond Res. 2005;19:677-683.

6. Amiri-Khorasani M, Sahebozamani M, Tabrizi $\mathrm{KG}$, et al. Acute effect of different stretching methods on Illinois agility test in soccer players. J Strength Cond Res. 2010;24:2698-2704.

7. Jaggers JR, Swank AM, Frost KL, et al. The acute effects of dynamic and ballistic stretching on vertical jump height, force, and power. J Strength Cond Res. 2008;22:1844-1849.

8. Opplert J, Babault N. Acute effects of dynamic stretching on muscle flexibility and performance: an analysis of the current literature. Sports Med. 2018;48:299-325.

9. Chen CH, Chang CK, Tseng WC, et al. Acute effects of different warm-up protocols on sports performance in elite male collegiate handball players. J Strength Cond Res. 2020, doi: 10.1519/JSC.0000000000003547

10. Niles B, Sinclair P. The effects of self-myofascial release compared to dynamic warm-up on muscle performance (Doctoral dissertation, Azusa Pacific University), 2020.

11. McKenney K, Elder AS, Elder C, et al. Myofascial release as a treatment for orthopaedic conditions: a systematic review. J Athl Train. 2013;48:522-527.

12. Beardsley C, Škarabot J. Effects of selfmyofascial release: A systematic review. J Bodyw Mov Ther. 2015;19:747-758.

13. Patel DG, Vyas NJ, Sheth MS. Immediate effect of application of bilateral self mo $^{-}$fascial release on the plantar surface of the foot on hamstring and lumbar spine flexibility: A quasi experimental study. Foot. 2016;3:7.

14. Le Gal J, Begon M, Gillet B, et al. Effects of selfmyofascial release on shoulder function and perception in adolescent tennis players. Journal 
of Sport Rehabilitation. 2018;27:530-535.

15. Fairall RR, Cabell L, Boergers RJ, et al. Acute effects of selfmyofascial release and stretching in overhead athletes with Glenohumeral Internal Rotation Deficit. J Bodyw Mov Ther. 2017;21:648-52.

16. Wiewelhove T, Döweling A, Schneider C, et al. A meta-analysis of the effects of foam rolling on performance and recovery. Front Physiol. 2019;10:376.

17. Debski P, Bialas E, Gnat R. The parameters of foam rolling, self-myofascial release treatment: a review of the literature. Biomedical Human Kinetics. 2019;11:36-46.

18. Fernández-Cuevas I, Sillero-Quintana M, Garcia-Concepcion MA, et al. Monitoring skin thermal response to training with infrared thermography. New Stud Athl. 2014;29:57-71.

19. Holey LA, Dixon J, Selfe J. An exploratory thermographic investigation of the effects of connective tissue massage on autonomic function. J Manipulative Physiol Ther. 2011;34:457-462.

20. Ayala F, de Baranda PS, Croix MDS, et al. Absolute reliability of five clinical tests for assessing hamstring flexibility in professional futsal players. J Sci Med Sport. 2012;15:142147.

21. Plisky PJ, Gorman PP, Butler RJ, et al. The reliability of an instrumented device for measuring components of the star excursion balance test. N Am J Sports Phys Ther. 2009;4:92-99.

22. Pauole K, Madole K, Garhammer J, et al. Reliability and validity of the T-test as a measure of agility, leg power, and leg speed in college-aged men and women. J Strength Cond Res. 2000;14:443-450.

23. Behm DG, Cavanaugh T, Quigley P, et al. Acute bouts of upper and lower body static and dynamic stretching increase non-local joint range of motion. Eur J Appl Physiol. 2016;116:241-9.

24. Richman ED, Tyo BM, Nicks CR. Combined effects of self-myofascial release and dynamic stretching on range of motion, jump, sprint, and agility performance. J Strength Cond Res. 2019;33:1795-1803.

25. Rana KS, Lehri A, Ramteke S. Acute effects of dynamic versus static stretching on explosive agility of young football players. Journal of Exercise Science and Physiotherapy. 2018;14. DOI:10.18376/jesp/2018/v14/i1/111294.

26. Chtourou H, Aloui A, Hammouda O, et al. Effect of static and dynamic stretching on the diurnal variations of jump performance in soccer players. PLoS One. 2013;8(8):e70534.

27. Jeong Y, Park J, Yu J, et al. Immediate effects of release ball massage and self-stretching exercise on hamstring's temperature, range of motion and strength in 20's women. Journal of International Academy of Physical Therapy Research. 2019;10:1739-1745.

28. Murray AM, Jones TW, Horobeanu C, et al. Sixty seconds of foam rolling does not affect functional flexibility or change muscle temperature in adolescent athletes. International Journal of Sports Physical Therapy. 2016;11:765.

29. Su H, Chang NJ, Wu WL, et al. Acute effects of foam rolling, static stretching, and dynamic stretching during warm-ups on muscular flexibility and strength in young adults. J Sport Rehabil. 2017;26:469-477.

30. Adams T, Carlson A, Hunt J, et al. Effect of dynamic stretching and self-myofascial release on muscle power and flexibility. International Journal of Exercise Science: Conference Proceedings, 2016;8(4):36.

31. Nichol L, Battey G, Mitchell S, et al. Effects on dynamic and static stretching and selfmyofascial release on muscle power and flexibility. International Journal of Exercise Science: Conference Proceedings, 2017;8:51.

32. De Benito AM, Valldecabres R, Ceca D, et al. Effect of vibration vs non-vibration foam rolling techniques on flexibility, dynamic balance and perceived joint stability after fatigue. PeerJ. 2019; 7: e8000.

33. Grabow L, Young JD, Byrne JM, et al. Unilateral Rolling of the foot did not affect nonlocal range of motion or balance. J Sports Sci Med. 2017;16:209-218.

34. Leblebici H, Yarar H, Aydın EM, et al. The acute effects of different stretching on dynamic balance performance. International Journal of Sport Studies, 2017;7:153-159.

35. Denerel N, Ergün M, Yüksel O, et al. The acute effects of static and dynamic stretching exercises on dynamic balance performance. Spor Hekimliği Dergisi, 2019;54:148-157.

36. Henning CJ, Stovern O, Porcari JP, et al. The acute effects of foam rolling on ankle and knee range of motion, hamstring flexibility, agility, and vertical jump height. International Journal of Research in Exercise Physiology, 2019;14:4454 .

37. Peacock CA, Krein DD, Silver TA, et al. An acute bout of self-myofascial release in the form of foam rolling improves performance testing. Int $\mathrm{J}$ Exerc Sci. 2014;7:202.31

38. Dallas G, Theodorou A, Paradisis G. The effect of different duration of dynamic stretching on sprint run and agility test on female gymnast. Journal of Physical Education and Sport. 2019;19:268-272. 